\title{
TEACHING VOCABULARY ON PHRASAL VERBS THROUGH GUESSING STRATEGY TO THE ELEVENTH MIA GRADE STUDENTS OF SMA SANTO PETRUS MEDAN IN THE ACADEMY YEAR OF 2016/2017
}

\author{
Aleixia Sandopa Br Ginting, Viator Lumban Raja, Karisma Tarigan \\ Catholic University of Saint Thomas \\ Email : viator_lumbanraja@ust.ac.id
}

\begin{abstract}
Vocabulary, as one of the knowledge areas in language, plays a great role for learners in acquiring a language. The vocabulary mastery affects someone's ability in using the language either in spoken or written form. The objectives of this research are to find out the result and the response of students towards the teaching vocabulary on phrasal verbs to the eleventh MIA grade students of SMA Santo Petrus Medan after having been taught through guessing strategy. This research is a Classroom Action Research which is conducted by applying guessing strategy. After six meetings, it can be seen that there is a significant improvement of students' vocabulary on phrasal verbs. The result of this research shows that the students' mean score in pre test is 70,71 with $50 \%$ and in post test mean score is 91,28 with $94 \%$ of the students got score $>75$. It shows that there is a significant mean score improvement between pre test and post test about $44 \%$. The responses of students to the teaching vocabulary on phrasal verbs through guessing strategy is good with $56 \%$ of agree respond category and 38\% of strongly agree respond category. It is suggested that teachers use guessing strategy in teaching vocabulary on phrasal verbs to the students in senior high school to improve their speaking skill.
\end{abstract}

Keywords: Vocabulary Mastery, Phrasal Verbs, Guessing Strategy

\section{INTRODUCTION}

\subsection{The Background of the Study}

Language is a tool which is used for interacting and communicating with each other. Language cannot be separated from human's life both in oral and in written. Lyons (1981:4) states that language is an institution which human can communicate and interact with others by using both oral and written form. Based on the expert's definition, we know that language has important role in daily life.

English is used in Indonesia as a foreign language. English is the language of diplomacy and international communication, bussiness, tourism, education, science, computer technology and internet. Taking a deep concern on global competition, where English competence is absolutely needed by government, has included English as one of subjects tested on the National Exam (Brown 2000:118). Now, English is taught in schools, from playgroups until university level.

Learning English nowadays is a must for students from Junior High Schools to Senior High Schools or Vocational High Schools. Nowadays, many teachers

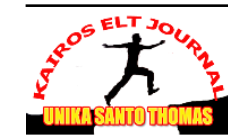


think that students should learn to speak the language when interacting to others. But, for achieving a good speaking skill students at least must know how they comprehend a text, pronounce a word, and read a text. In addition, they should have good grammar and adequate vocabulary. Overall, one of some important speaking components is vocabulary mastery.

Vocabulary, as one of the knowledge areas in language, plays a great role for learners in acquiring a language. The vocabulary mastery will affect someone's ability in using the language either in spoken or written form. Although someone has known sentence structure but if he/she does not master vocabulary, he/she will remain unable to say or write anything and the grammar knowledge will be useless.

In another case, for example in reading there are many problems which are faced by the students. One of them is the difficulty in comprehending the meaning of the words. The lack of the students' vocabulary is one of the causes why many students feel it difficult to understand the text. This problem makes the students not interested in reading. The students were also lazy to open the dictionary, and they could not identify the meaning of the difficult words, especially phrasal verbs.

One of six kinds' vocabulary is multi word units. Most of multi word units form phrasal verbs and idioms. Phrasal verbs are combination of a verb, an adverb or preposition in which the meaning cannot always be understood as the sum of its parts (Beyer, 2007:18). It is necessary to master phrasal verbs because they are frequently used in both oral and written material. Since English is a foreign language, it is understandable why most students face difficulties in understanding word meaning, especially dealing with phrasal verbs.

The phrasal verbs play rather an indispensable role in English particularly in written form. Phrasal verbs are noted as one which presents considerable difficulties for learners. One of the causes of the difficulties is that phrasal verbs are hard to memorize in terms of the meaning. For examples:

1. The teacher called off the test.

2. The company turned down Bill's offer.

3. The man walked up the hill.

From the sentences above, it can be seen the phrasal verbs with their separated meaning. Someone can also use ordinary verbs instead of phrasal verbs but in fact the use of phrasal verbs will tell the degree of one's English level. When the above sentences are changed with ordinary verbs, they will be read like these:

1. The teacher cancelled the test.

2. The company refused Bill's offer.

3. The man ascended the hill.

This can be really frustrating because using the wrong phrasal verbs can change the whole sentences. And what is worse is that each phrasal verb can have multiple definitions. That is why the mastery of phrasal verbs is very important in order to understand English well. Understanding phrasal verbs is one of the advanced and fundamental aspects of vocabulary/word knowledge. By learning 
phrasal verbs, students will be able to speak more naturally and be more acceptable in the society.

Teaching phrasal verbs to the students is not easy. Teachers must give a high motivation to the students of the importance of reading in their lives. One of effective strategies which teachers must also apply in order to make the students able to identify the meaning of phrasal verbs, is guessing strategy from the context in which students learn how to guess the unknown/difficult words based on the contextual clues given in the sentence. Qian (2005:87) says that guessing strategy is the most important strategy for reader/learner to find out the new vocabulary in a situation where learners can not open the dictionary in examination, for example, this strategy is significant for them.

This study needs to be done because based on the writer's experience when having Teaching Practice Program 2016 at SMA Santo Petrus Jln. Luku 1 No.1 Medan, the problems of the study at the school which students got are students are lack of vocabulary mastery especially on phrasal verbs and they are also lazy to open dictionary when they find out the difficult or unknown word in a text. They need support to learn vocabulary on phrasal verbs and also the students like to learn something new. They are expected to be able to read and understand the text well particularly to identify the meaning of the difficult words like phrasal verbs. Although learning to acquire phrasal verbs can be problematic for the learners, it is challenging for the teachers to teach them, it is important for teachers to help the students to acquire them.

One of the study concerning this phrasal verbs through guessing strategy was conducted by Novianti (2014) which entitled: "Contextual Guessing Strategy Instruction and Studnets' Mastery on Phrasal Verbs" at State Vocational School in Tasikmalaya. There was a positive effect in teaching students' vocabulary mastery on phrasal verbs through guessing strategy. This can be seen from the mean of pretest 30.20 , and it became 34.18 in the post test. Another of the study concerning this phrasal verbs through guessing strategy was conducted by Achmad (2013) which entitled: Developing English Vocabulary Mastery through Meaningful Learning Guessing Approach" at Competitive Class of Junior High School in Gorontalo City, Indonesia. There are also a positive effect in teaching students' vocabulary mastery through guessing strategy The writer feels interested in conducting a research entitled "Teaching Vocabulary on Phrasal Verbs through Guessing Strategy to the Eleventh MIA Grade Students of SMA Santo Petrus Medan in the Academic Year of 2016/2017.

\section{REVIEW OF LITERATURE}

\subsection{Vocabulary}

Vocabulary is a collection of words by a speaker, a listener, a writer or a reader in the language competence which has a meaning or meanings (Nauth,1995:414). It means that a speaker construsts some words to make sentences 
for their communication with other people. Vocabulary is not a syllabus but a list of words that teachers prepare for their learners to memorize and learn by heart. Memorizing may be good and useful as a temporary technique for tests, but not for learning a foreign language. What students need to know regarding vocabulary is the word meaning and the word use. Therefore, vocabulary has an important role to help the students understand the meaning of words, and how they are used in sentences.

Vocabulary is collected through language, conversation and a dictionary used by people in verbal communication. This vocabulary may consist of content words or function words. One of the content words is verb which can be composed of single words or double ones. It is not difficult to understand the meaning of the verb go alone, but it matters when it is combined with other prepositions, particles, or adverbs such as go on, go through, go into, go out, go forward, go about, etc. The meaning of these combined verbs can not always be traced from the individual words. Sometimes they produce new meanings. Some people find difficult meaning when they read a text using phrasal verbs or difficult to understand when native speaker uses phrasal verbs in speaking.

\subsection{Vocabulary Mastery}

Mastery is skill knowledge that makes one master of a subject (Allen, 2000:856). Subject in this case is vocabulary in a foreign language which is learnt by students. Hornby (1989:631) also defines that mastery is the skill or knowledge or master. In addition, Harmer (2002:13) points out that without grammar very little can be conveyed, but without vocabulary nothing can be conveyed. It means that no language exists without vocabulary.

Reffering to the concept of mastery, vocabulary mastery is a someone's proficiency in using words and their meaning appropriately in language. By reading a text, learners will be accustomed to looking up the dictionary, guessing the words, and using the words in the context properly. Good mastery of vocabulary helps the learners express their ideas precisely. By having many stocks of words, learners will be able to comprehend the reading materials, to catch someone's talk, to give a response, to speak fluently, and to write some kinds of topics.

As we know, vocabulary is also important in language learning which has to be mastered by students to develop the language skill; especially in speaking that students should have adequate vocabulary. Therefore, success in learning English requires vocabulary acquisition. A large vocabulary can not guarantee the learner's competence in learning English but inadequacy of vocabulary will obstruct their chances to make success in learning English.

Resnick (1989:67) argues that the students should be involved intensively in acquiring vocabularies. Thus, that vocabularies will be realized and internalized in their own cognitive systems that may be utilized in their social language interaction and academic activities.

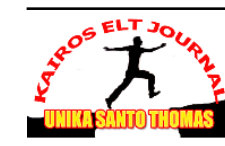




\subsubsection{The Importance of Vocabulary}

Vocabulary is one element of the language that should be learnt and taught. It will be hard to master a language without mastering or understanding a certain number of vocabularies. Vocabulary is the first step to be taught before teaching other aspects of language. McCharty (1990:8) states that the importance of vocabulary in language learning is as follows: "No matter how successfully sounds of second language are mastered, without words to express a wider range of meanings, communication in a second language just cannot happen in any meaningful way.

It has to be realized that the student's ability to read, to listen, to write, and to speak is conditioned by their vocabulary. It makes vocabulary becomes the basic element to master the four language skills, namely listening, speaking, reading, and writing. In reading ability, vocabulary helps learners in comprehending the text. In writing, it helps them to expand their ideas based on the topic sentences that they want. In listening, they comprehend and understand what other person speaks. In speaking ability, vocabulary facilitates the learners to explain their ideas orally. In addition, Coady and Huckin (1997:5) argue that vocabulary is a central and critical importance to typical language learner. Without having adequate vocabulary, a language learner will not be able to master the language skills. The meaning shows that vocabulary must not be neglected by anyone who learns a language.

Schmitt (2000:55) emphasizes that "lexical knowledge is central to communicative competence and to the acquisition of a second language". The importance of vocabulary is demonstrated daily in and out the school.

\subsubsection{The Teaching of Vocabulary}

Recent research indicates that teaching vocabulary may be problematic because many teachers are not confident about the best practice in vocabulary teaching and at times do not know where to start to form an instructional emphas is on word learning. Teaching words is a crucial aspect in learning a language as languages are based on words (Thornbury, 2002:56).

In school, vocabulary can not be taught in isolation. It is must be gathered with another lesson of English for example in reading. However, the teaching of vocabulary in classroom is not too emphasized. The writer observed that the teacher asked the students to write down difficult words when they read a text and find some new words. Students noted the meaning of difficult words in notes of their vocabularies. In learning teaching process, teacher did not force her students to memorize it and vocabularies material is not examined. Both teachers and students agree that acquisition of the vocabulary is a central factor in teaching a language (Walters, 2004:90). The teacher should prepare and find out the appropriate techniques, which will be implemented to the students.

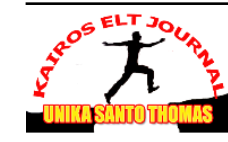


A good teacher should prepare himself or herself with various and up-todate techniques to teach vocabulary. Teachers need to be able to master the material of vocabulary in order to be understood by students, and make them interested and happy in the teaching and learning process in the classroom. The teachers should be concerned that teaching vocabulary is something new and different from students' native language. They are required to prepare good techniques and suitable material in order to gain the target of vocabulary.

\subsection{Types of Vocabulary}

Harmer (1991:56) distinguishes two types of vocabulary, they are productive and receptive vocabulary. The first type of vocabulary refers to the one that the students have been taught and that they are expected to be able to use. Meanwhile, the second one refers to the words which the students will recoqnize when they meet them, but which they will probably not be able to pronounce. Haycraft (in Hatch and Brown, 1995:78) also indicate these two types of vocabulary.

\subsubsection{Receptive Vocabulary}

Receptive vocabulary is words that learners recoqnize and understand when they are used in context, but which they cannot produce. It is vocabulary that learners recoqnize when they see or meet in reading text but do not use it in speaking and writing (Stuart, 2008:78).

\subsubsection{Productive Vocabulary}

Productive vocabulary is the words that the learners understand and can pronounce correctly and use appropriately in speaking and writing. It involves what is needed for receptive vocabulary plus the ability to speak or write at the approriate time. Therefore, productive vocabulary can be addressed as an active process, because the learners can produce the words to express their thoughts to others (Stuart,2005:81).

\subsubsection{Multi Word Units}

According to Thornbury (in Al-Baekani, 2015:69), there are some ways of presenting a word meaning namely:

a. Word Classes; the words play different roles in a text. They fall into one of eight different word classes such as nouns, pronouns, verbs, adjectives, adverbs, prepositions, conjuctions, and determiner.

b. Word Families; how words may share the same base or root but take different endings. A word family comprises the base word plus its inflextion and its most common derivations. For example: play+er= player, re+play= replay, play+ful= playful.

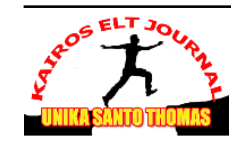


c. Collocation; how words "couple up" to form compounds, and how they "hurt in packs" in the shape of multi-word units. It is seen as part of a continuum of strength of association: a continuum that moves from compound words (second-hand, record player), through multi-word units or lexical chunks (bits and pieces), including idioms (out of the blue) and phrasal verbs (do up), to collocations of more or less fixedness (set the record straight, set a new world record).

d. Synonyms; words that share a similar meaning. Thus: old, ancient, antique, aged, elderly are all synonyms in that they share the common meaning of not young/new. Synonyms are similar but seldom the same.

e. Antonyms; wors with opposite meaning - like old and new.

Roger (in Setiawan, 2010:16) says that multi word items is a lexical item that may consist of more than one word, as in a compound like tennis shoes, or rally car or a phrasal verbs such as to put some one up. Walton (2009:10) said that multi word units are verbs that consist of more than one word. There are types of multi word units: prepositional verbs, phrasal verbs, and phrasal prepositional verbs

1. I ran into my roommate on my way to class, means meet by chance.

2. Our car broke down on the way home from Tulsa, means fail to function.

3. The attendences grew restless when they learned we had run out of pizza, means short of; lack of.

\subsection{Guessing Strategy}

Based on Qian's notion (2005:87), guessing strategy is the most important strategy for reader/learner to find out the new vocabulary in a situation where learners can not open the dictionary in examination, for example, this strategy is significant for them. Phongphio and Schmitt (2006:90) even recommended the use of guessing strategy for multi-word verbs such as phrasal verbs.

Letting foreign language learners infer the meaning of an unknown word occurringin a target text, using the information in the context seems likely to be an effective and efficient for target language acquisition (Hulstjin, 2003:113). With respect to English phrasal verbs, English second language learners find them complicated, difficult, and hard to memorize (Buyukkarci, 2010:13). From a semantic perspective, some of the meaning are completely idiomatic in which the phrasal verbs cannot be deduced by analyzing the separate elements (verb and particle/s), and when put together they yield a completely different meaning.

It seems likely that presenting phrasal verbs in the context and asking the students to guess the meaning from the context not only enables the students to deduce the meaning and realize the usage of them, but also, it could lead to a better retention of phrasal verbs as long as the students give more cognitive effort in the guessing process. For example, students find sentences below:

1. Let's hang out. I miss all of you, friends.

2. Hold on, I can't hear you! No signal here.

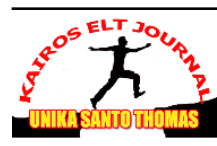


3. Don't come in, John. They are having a meeting.

From the examples above, the writer hopes that students will guess the meaning from its context in each sentence.

1. Somebody invites his friends to gather together in a place because he is missing his friends.

2. Somebody asks for the other to wait a minute because he can not hear one's voice in the telephone.

3. Someone says John not to enter the room because meeting room is being held.

Guessing strategy is strategy that is used to infer or guess the meaning of the target word based on the interpretation of its immediate context with or without reference to the world knowledge (Haastrup in Cetinavci, 2014:2671). On the other hand, it is necessary to rely on someone's own experience and background knowledge to figure out the meaning of a word. Sometimes, the meaning of the words can be guessed just by using the knowledge of the world and how things work (Robinson, 2010:4).

Guessing strategy involves general skills of interpreting surrounding text, predicting, and testing predictions which enhance vocabulary mastery as a whole (Nation \& Coady, 1988:90). In addition, guessing has been advocated instead of dictionary use because stopping to use a dictionary interrupts the flow of reading (Brown, 1972:67). One important objective of studies into language learning strategies is often to determine effective ways of learning a new language (O’Malley \& Chamot, 1990:45). Guessing, memorizing, and repeating of new English words are some of the vocabulary learning strategy commonly used.

\subsubsection{Procedures of Guessing Strategy}

There are some procedures that can be followed by learner in conducting the techniques of guessing strategy. The procedure of guessing strategy is aimed to help the learner find the meaning of the unfamiliar word. It is very important to follow the procedure to decrease the wrong guessing. According to the Schmitt (2000:42), there are five steps on conducting the technique of guessing word: Step 1:

The students have to look at the unknown word and decide its part of speech, is it a noun, a verb, an adjective or an adverb. If they have known the part of speech of the word, the part of speech of the word drive the students on the meaning of the unfamiliar word or context means.

Step 2:

The students have to look at the clues or sentence containing the unfamiliar word.

Step 3:

The students have to look for the relationship between the clause or sentence containing the unknown word and the other sentences or paragraphs.




Step 4:

The students have to use the knowledge that they have gained, from 1-3 guessing the meaning for the word. It cannot be denied that the mastery of vocabulary much influences on conducting the technique of guessing word from context. The more the students master the vocabulary the more they can do the techniques in the easiest way.

Step 5: Check that your guess is correct.

1. See the part of speech of your guess is the same as the part of speech of the unknown words. If it is different, then something is wrong with your guess.

2. Replace the unknown word with your guess. If the sentence makes sense, your guess is probably correct.

3. Break the unknown word into separable and inseparable, if possible. If we found the meaning of the separable and inseparable, correspond to your goals.

\subsubsection{Teaching Vocabulary using Guessing Strategy}

A student who lacks the vocabulary will find difficulties in language learning process and has little opportunity to be successful in developing the four language skills (M.Lightbown,2006:34). To communicate with each other, especially the foreigner, we need to master vocabulary as much as possible. Vocabulary is the most important factor that students should be mastered. Students often find difficulties to understand some new words or unknown words in English while reading a text. Teacher asks students learn many vocabularies by guessing strategy of new words or unknown word based on the meaning in the sentences. Teachers need to teach vocabulary by memorizing first of single words, so that in two words or multi words unit like phrasal verbs, students will be easier to find the meaning by guessing from the basic verbs.

Teaching vocabulary by using guessing strategy is an effective strategy or technique in teaching that will make teachers successful in learning process of vocabulary. Especially in learning material of phrasal verbs, the deep knowledge, focus in vocabulary, is needed (Al-Baekani,2015:56). Try to guess meaning of unknown word means to infer the meaning that includes in a word. Thus, teaching vocabulary for students by guessing strategy is one way to develope the achievement even for students and teachers.

\subsubsection{Advantages of Guessing Strategy}

Teaching the meaning of unknown words to native first language learners, the "guessing strategy" has been applied to second language learners as well. According to Cetinavci (2014:14), we can justify the use of the guessing strategy due to the numbers of words in the English language that actually need to be learned.

Barnett (1988:11) and Laufer (1996:21) state that guessing is a very sophisticated strategy. As English Second Language (ESL) teachers, in many cases

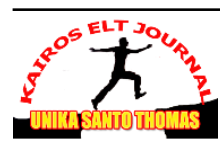


we deal with good strategy. Each and every student is educated no matter how disadvantaged they are, guessing strategy gives students many advantages, they are:

1. In a test, students are faced with the difficulty in comprehending the meaning of the words, they are not permitted to open the dictionary. So the effective strategy that students can use is by guessing the meaning based on its sentences.

2. Guessing strategy are responsible for helping and guiding the students to develop a vocabulary by correlating listening, speaking, writing and reading. They need the oral component, they need to be taught vocabulary, and they must hear a great deal of meaningful language.

3. Guessing strategy helps students to find out the inferential skill that is needed to decide which meaning is correct, based on the understanding of the clue in sentences, and for second language learners this often depends on the extent of global knowledge.

4. No matter what level the students are in, they will often come across diffic ult words in texts they are exposed to. Inferring and guessing meaning of unfamiliar words is a strategy which is worth developing.

Brown (1972:22) assumes that the teacher must assist in finding the definitions since even the dictionary may need a guessing strategy. The first thing that a learner does to understand a difficult word is to look it up using the nearest dictionary. If it is allowed there are techniques learners may use to get the meaning of such vocabulary items. One of these techniques is guessing meaning from context. As teachers, we can not assume that second language learners have guessing strategy abilities of any amount of vocabulary storage.

\section{RESEARCH METHOD}

\subsection{Research Design}

This study uses Classroom Action Research (CAR). The data of this study are quantitative and qualitative data. The quantitative data will be collected by using written test which consists 25 questions. While the qualitative data will be collected by using observation, questionnaires and field notes.

This study also involves four phases in each cycle which are essential as proposed by Kemmis and McTaggart (in Burns, 2010:7). Those phases are planning, acting, observing, and reflecting. Each cycle has three meetings. The action that the teacher does in first cycle influences the second cycle because it is needed to improve what is missing in the first cycle. It makes the teacher prepare the action well so that the learning and teaching process can work better than before.

\subsection{The Location and Time of the Study}

This study conducted at SMA Santo Petrus Medan. It is located on Jln. Luku 1 No.1, Kwala Bekala, Medan Johor, Kota Medan, Sumatera Utara 20146, Indonesia. This study started in April 2017 on the Academy Year of 2016/2017. 


\subsection{The Subject of the Study}

The subject of this study is the eleventh grade students of SMA Santo Petrus Jln. Luku 1 No.1 Medan. There are three classes of the eleventh grade students which consists of one science classroom and two social classrooms. Class XI MIA which consists of 38 students, 12 males and 26 females, is taken out as the subject of the study to be treated with Guessing Strategy in Vocabulary on Phrasal Verbs. The writer chooses this class as the subject of this study because this class has problems in mastering vocabulary particularly on phrasal verbs that are the students are still lack of vocabulary and they are also lazy to open dictionary when finding difficult, new, or unknown words. The writer thinks this class can give feed back and participation well based on the Teaching Practice Program's experience.

\subsection{The Instrument of Collecting Data}

In collecting the data, the writer uses different instruments such as tests, observation, questionnaires and field notes. The tests include pre - test and post test are used as an indicator to see the result of teaching vocabulary on phrasal verbs after they are taught with guessing strategy. The test is constructed based on the English book of the eleventh grade students of SMA Santo Petrus Jln. Luku 1 No. 1 Medan and the other resources. The observation in this study can be used as a medium to see the attitude of the students in learning process. Moreover, through observation, the writer can find any other information that is not fully expressed throughout the other data collection like the motivation or spirit of the students in learning process.

\subsection{The Techniques of Data Analysis}

This study uses qualitative and quantitative data. The qualitative data is used to describe the situation during the teaching process and the quantitative data is used to analyze the score of the students. The qualitative data is obtained the observation sheet and the quantitative data from the score of vocabulary on phrasal verbs test as to know the mean of the students' score of assessment given in each treatment.

The quantitative data are obtained based on Arikunto (2010:315) to find out the class mean score in each cycle. The writer applies the following formula:

Where : $\quad \overline{\mathrm{X}} \quad=$ The mean score of the students

$$
\overline{\mathrm{X}}=\frac{\sum \mathrm{x}}{N} \mathrm{x} 100 \%
$$

$\Sigma \mathrm{x} \quad=$ The total score of the students

$\mathrm{N} \quad=$ The number of the students

In addition, to evaluate the students' vocabulary on phrasal verbs, the writer gave 15 multiple choice test and 10essays for each cycle. Each question for multiple choice gave score two (2) point for each right answer, while for an essay test gave

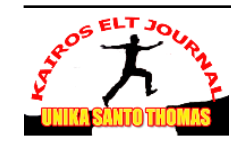


score seven (7) point for each suitable answer. The test will be scored by using score rank from 0-100 by counting the correct answer and applying the following formula:

$$
S=\frac{R}{N} X 100 \%
$$

Where : $\quad \mathrm{S}=$ score of test

$\mathrm{R}=$ Number of the correct answer

$\mathrm{N}=$ Number of the items

To categorize the number of the students who get a score above 75 will calculated by applying the following formula:

$$
\mathrm{P}=\frac{F}{\mathrm{~N}} X 100 \%
$$

Where: $\quad \mathrm{P}=$ The percentage of students who get the score 75

$\mathrm{F}=$ The number of students who get the score above 75

$\mathrm{N}=$ The total number of students who do the test

\section{DATA ANALYSIS AND DISCUSSION}

\subsection{The Data Analysis}

In the data analysis, there are two types data which will be analyzed to find out the result of teaching vocabulary on phrasal verbs and the response of students to the teaching vocabulary on phrasal verbs after having been taught through guessing strategy. The data analysis of this study were qualitative data and quantitative data.

\subsection{Discussion}

The result of the teaching vocabulary on phrasal verbs by guessing strategy could improve the students' vocabulary on phrasal verbs. Guessing strategy was one of techniques that could make the students easier in learning English especially in the vocabulary achievement. This study had proved the effectiveness of using guessing strategy. It was shown in the table 4.1.2.1, the students' score from pre test, formative test, and post test. By applying guessing strategy, the score of the students' vocabulary on phrasal verbs kept increasing from the pre-test until post test. It was proved by the data which showed that the mean of the students in post test $(91,28)$ was higher than that of the formative test $(78,10)$ and also higher than that of the pre test $(70,71)$.

Students' score data in the post test showed that the mean of students' scores were higher than the mean of the students' score in the formative test and also better than the pre test. From the table of the percentage of achievement students on vocabulary (table 4.1.2.2), in the formative test, students who got score above 75 were higher than in the pre test and also better its percentage of achievements in the 
post test. From the students' score data, the students' vocabulary achievement was better in every test. Based on the result, it was found out that the use of guessing strategy had increased students' achievement vocabulary on phrasal verbs. It indicates that the use of guessing strategy was effective in improving students' vocabulary achievement.

The response of the students to the teaching vocabulary on phrasal verbs through guessing strategy can be seen in the table of questionnaire. Their interest, the ability of teacher, the use of guessing strategy, the appropriateness of guessing strategy, and the process of learning phrasal verbs had became descriptions which were asked for students to fill it. It was proved in the table of questionnaires in Appendix D. From the result of questionnaire, the students showed that there was improvement in students' vocabulary by their expression, interest, and excitement during process learning of phrasal verbs. In addition, their improvement in learning vocabulary on phrasal verbs through guessing strategy was also showed in observation sheets and field notes. Attitude of students and situations in classroom had been explained in observation and field notes. Thus, it can be concluded that the use of guessing strategy could improve the students' vocabulary on phrasal verbs. And guessing strategy is effective to be used by teacher and help teacher to teach vocabulary well.

\section{CONCLUSIONS AND SUGGESTIONS}

\subsection{Conclusions}

Concerning with the result of the test item that has already given to the students, the writer can take conclusion. The conclusion are:

1. Teaching vocabulary on phrasal verbs through guessing strategy was effective especially in SMA Santo Petrus Jln. Luku 1 No.1 Medan 2016/2017. After the writer analyzes the data, it is found that students' achievement of vocabulary on phrasal verbs is improved from pre test to post test by using guessing strategy. The improvement of students' total mean score for pre test are significant $(70,71)$, formative test $(78,10)$, and post test $(91,28)$. The students' score continuously improved in each test. Therefore, guessing strategy significantly improves students' vocabulary on phrasal verbs.Furthermore, it can be concluded that learning guessing strategy is effective to be used in teaching vocabulary especially on phrasal verbs. Based on the increase percentage (44\%), from pre test $(50 \%)$ to post test $(94 \%)$, guessing strategy is also useful in process teaching learning on vocabulary.

2. The response of students in the teaching vocabulary on phrasal verbs through guessing strategy are categorized good. From the result of questionnaire, the students showed that there was improvement in students' vocabulary on phrasal verbs through guessing strategy by their interest, expression, and excitement during learning process in classroom. In addition, their improvement in learning vocabulary on phrasal verbs through guessing 
strategy was also showed in observation sheets (Appendix C) and field notes (Appendix B). In another language, based on the result of data questionnaire, observation sheets, and field notes, can be concluded that the use of guessing strategy for students is acceptive in learning vocabulary. Students became more easier comprehend learning vocabulary especially on phrasal verbs and can be easier to understand the excess of guessing strategy in vocabulary on phrasal verbs (separable and inseparable).

\subsection{Suggestions}

Based on result of study that was performed at Second Semester of Eleventh Grade at SMA Santo Petrus Medan in 2016/2017, the writer would like to give some suggestion as follow:

1. During process learning of treatment in classroom, there are several weaknesses that writer found such as: the use of time unmaximal yet, lack of students' focus/consentration, and run out of the exercises to be given for students. Therefore, the writer suggest for the next researcher to maximise time effeciently even in employing material or in implementation technique of learning, also should be more raise and add the exercises of material which will give to students. The students should pay attention to teaching of teacher about vocabulary by using guessing strategy and following the rules of the teacher' teaching.

2. Based the data questionnaire result, from the level of scoring, there were many students still categorized agree than strongly agree for each number of question, and also there were some students categorized quite agree. Therefore, the writer suggest the next researcher try to make students categorizing the scoring of questionnaire data strongly agree dominantly, also try to minimize none students categorize quite agree, disagree, or strongly disagree and should make steps of teaching material efficiently and effectively especially in teaching vocabulary. It is also suggestedfurther researcher to make good preparation in applying guessing strategy when conduct the research related to achieve better result.

3. It is also suggested for the teachers to design a good scenario of teaching learning process and make good preparation to apply guessing strategy in teaching vocabulary in particularly on phrasal verbs. The teachers should use guessing strategy to increase students' vocabulary on phrasal verbs, in order to the using or mastery of students' vocabulary is more complex (not only simple words) and students' vocabulary more upgrade than before. Based on result, using guessing strategy is as the alternative aid to help students in adding new vocabulary and the teacher should give variation in carrying out the materials through the various way.

\section{BIBLIOGRAPHY}

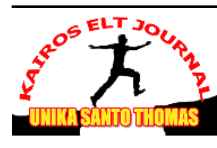


Al-Baekani, Abdul Kodir. The Effects of Teaching Technique and Vocabulary Mastery Towards Student's Speaking Skill. Journal Pendidikan Unsika Issn 2338-2996,3(1),2015.

Allen, D. 2000. Microteaching. Massachussetts: Addison-Wesley Publishing Company.

Almaela, Moises \& Aquilino Sanches. 2007. Words as 'Lexical Units' in Learning/Teaching Vocabulary. International Journal Of English Studies,7(2), 2007,21-40.

Arikunto, S. 2010. Prosedur Penelitian: Suatu Pendekatan Praktik. Jakarta: Rineka Cipta.

Azar, Betty Schrampfer. 1941-2003. Fundamentals of English Grammar: Third Edition with Answer Key. New York: Pearson Education.

Barnett \& Laufer. 1988-1996. The Effectiveness of Guessing Strategy. Cambridge: CUP.

Beyer, Thomas R. 2007. 501 English Verbs. Jakarta: Binarupa Aksara Publishing.

Brown, H.D. 2000. Teaching by Principle: An Interactive Approach to Language Pedagogy. San Fransisco: Longman.

Brown, James Wilson. 1972. Technology Media and Methods. California: McGrawHill.

Burns, Anne. 2010. Doing Action Researchi English Language Teaching: A Guide for Practitioners. New York: Routledge

Buyukkarci, K. 2010. Teaching Phrasal Verbs through Communicative Approach. Journal Of The Institute Of Social Sciences,(5),11-20.

Cetinavci, B.M. 2014. Contextual Factors in Guessing Word Meaning from Context in A Foreign Language. Social and Behavioral Sciences,116,2670-2674.

Coady and Huckin. 1997. Second Language Aquisition. A Rational for Pedagogy. Cambridge: Cambridge University Press.

Gellerstam, M. et al. 1996. “Don’t Give Up, Look it Up! Defining Phrasal Verbs for The Learner of English" in PROCEEDING EURALEX.

Gillett, Amy. 2011. English Fast \& Easy: Useful Phrases for Work and Everyday Life. Boston: Delapratasa Publishing. 
Harmer, Jeremy. 1991. The Practice of English Language Teaching. New York: Longman P.134.

Harmer, J. 2002. How to Teach Vocabulary. England: Longman.

Hatch, E \& C.Brown. 1995. Vocabulary, Semantics, and Language Education. Cambridge: Cambridge University Press.

Huang, S. \& Eslami,Z. 2013. The Use of Dictionary and Contextual Guessing Strategies for Vocabulary Learning br Advanced English. Canadian Centre Of Science And Education,3(3),1-7.

Hulstjin, J. 2003. Incidental and Intentional Learning. Malden: MA-Blackwell Publishing, Ltd.

Lyons, John. 1981. Language As A Communication and Linguistics. New York: Cambridge University Press.

McArthur, Tom., Beryl Atkins. 1974. Dictionary of English Phrasal Verbs and Their Idioms. Singapore: Pan Pasific Book Distibutors (s) Pte.

McCharty, Mickhael. 1990. Vocabulary. Oxford: Oxford University Press.

McCharty, Mickhael \& F. O'Dell. 2004. English Phrasal Verbs in Use. Cambridge: Cambridge University Press.

M.Lightbrown, Pasty and Nina Spada. 2006. How Language are Learned Third Edition. New York: Oxford University Press,P.96.

Nation, I.S.P \& Coady, J. 1988. Vocabulary and Reading. London: Longman, 97110. 1990. Teaching and Learning Vocabulary. Boston: MA.

Nauth, W. H. 1995. The World Book Encyclopedia. Chicago: World Book.

Novianti, Wiena. 2014. Contextual Guessing Strategy Instruction ans Students' Mastery on Phrasal Verbs. RJES,1(2), July-December 2014.

O’Malley, M. \& Chamot, A. 1990. Learning Strategies in Second Language Acquisition. Cambridge: Cambridge University Press.

Phillips, Deborah. 1952. Longman Preparation Course for the TOEFL Test. New York: Pearson Education, Inc.

Phongpio, T. Schmitt, N. 2006. Learning English Multi-word Verbs in Thailand. Thai IESOBULLETIN,19(2).122-136. 
Qian, D.D. 2005. Demystifying Lexical Inferencing: The Role of Aspects of Vocabulary Knowledge. Tesl Canada Journal, 22(2), 34-54.

Resnick, L.B. 1989. Knowing Learning, and Instruction. Hillsdale, New Jersey.: Lawrence Erlbaum.

Richard, J.C, and Renandya Willy A. 2002. Methodology in Language Teaching. Cambridge: Cambridge University Press.

Robinson, J. 2010. Understanding Vocabulary in Context. Retrieved from http://douglascollege.cal6co78c8cd7. on 2017

Schmitt, N. 2000. Vocabulary in Language Teaching. Cambridge: Cambridge University Press.

Setiawan, J. 2010. Lexical items in Vocabulary Mastery. Jakarta: Binarupa Aksara Publishing.

Shahrzad, A. 2011. The Effect of Instruction in Deriving Word Meaning on Incidental Vocabulary Learning in EFL Context. World Journal Of English Language,1(1),68-79.

Stuart, W. 2005-2008. Receptive and Productive Vocabulary Size of L2 Learners. Studies In Second Language Acquisition,30(1)7-95.

Thornbury, S. 2002. How to Teach Vocabulary. Harlow: Longman.

Yu-jing, H. 2010. Improving English Vocabulary Teaching in A Chinese University Environment in Indonesian. Journal Of English Language Teaching, 6(1), 1-12.

Walters, J.M. 2004. Teaching The Use of Context to Infer Meaning. A Longitud inal Survey of L1 and L2 Vocabulary Research. Language Teaching, 37(4), 243252.

Walton, Sam.M. 2009. Multi Word Verbs. Arkansas: College of Business. 